\title{
Identification of Business Model Complementarity and the Factors that Determine it in the Klaipeda City Incoming Tourism
}

\author{
Remigijus Kinderis \\ Klaipeda State University of Applied Sciences, Lithuania \\ Liepaja University, Latvia
}

Received: 11 September 2019. Revision received: 3 November 2019. Accepted: 12 November 2019

\begin{abstract}
The main goal of this research was to determine the complementarity of the business models of the investigated enterprises and the factors determining it in the Klaipeda city (Lithuania) incoming tourism. Research was based on the methodological approach of the qualitative research (the phenomenological case study). Data of the research were obtained by using the instrument of partially structured expert interview. As the results of the research, the concept of business model complementarity and the factors that determine it in the tourism business was theoretically analysed; the conceptual model of business model complementarity and the factors that determine it in the incoming tourism was identified, analysed in practice and presented as well. The research results can be used in several practical fields of activities: the obtained results allow to strengthen managerial impact to the creation and development of the potential partnerships; the research methodology is easily adaptable for the determination of business model complementarity of companies that operate in other business systems and prepared research instrument can be considered as a diagnostic tool for inter-organisational relations, it can be used to determine and evaluate the complementarity of company business models in various business systems.
\end{abstract}

Keywords: business model, complementarity, business model complementarity.

JEL classification: M10, M19

\section{Introduction}

The analysis of the scientific resources allows to state that the majority of scientists analyses business models and their mutual interaction in the context of value creation logic (Zott\& Amit, 2010; Teece, 2010; Chesbrough, 2010). It can be noted that new business model and their mutual relation research perspectives are gradually forming: cooperation between suppliers, customers and partners (Zott\& Amit, 2010; Ganushchak-Efimenko et al., 2018); creation of new or bigger value by combining internal resources (Johnson et al., 2008; Verstraete\&Estele, 2011); peculiarities of business model and strategy links (Casadesus-Masanell\&Ricart, 2010;Slávik\&Zagoršek, 2016; Androniceanu, 2017); selection of business model and market strategy (Zott\&Amit, 2010; Kaplan, 2012;Olinski, Szamrowski\&Luty, 2016); variety of business model levels (Schallmo\& Brecht, 2010; Wirtz et al., 2015). However, the research that would reveal the essence of the business model interaction result (complementarity) (its certain traits or identification characteristics), is missed. Fragmented researching of business model or their element complementarity and the existing variety of definitions does not reveal the 
individuality of the complementarity phenomenon. The analysis of the information sources of the management sciences allowsto state that research of business model complementarity is performed only fragmentary and passively, and the complementarity itself is deemed somewhat new object of research (Ennen\&Richter, 2010; Wirtz et al., 2015). Complementarity aspects are examined by authors, who research implementation of innovations (Cassiman\&Veugelers, 2006; Miravete\&Pernias, 2006; Świadek, 2018; Świadek et al., 2019), improvement of competitiveness and activity efficiency (Rivkin andSiggelkow, 2003), horizontal integration processes of companies (Lee et al., 2006), creation of the systemic activity effect in the organization (Cavaco \&Crifo, 2014). However, the research that would reveal the essence of the complementarity and the factors that determine it in the tourism business through the systemic approach is missed. Fragmented researching and the variety of interpretations do not reveal the uniqueness of the business model complementarity. The research that would examine the factors that determine the business model complementarity, identify the nature, intensity, orientation, and identification, is missed. Therefore, it is intended to research the aforementioned problematic aspects systemically, by employing theoretical approaches of business model, connection between organisations and complementarity.

The problem of the research is formulated by presenting question in research context: what traits and identification characteristics and factors determine business model complementarity in the incoming tourism?

The object of the research - business model complementarity and the factors that determine it.

The aim of the research - to determine the complementarity of the business models of the investigated enterprises and the factors determining it in the Klaipeda city incoming tourism.

Objectives of the research:

1. To analyse the concept of business model complementarity and the factors that determine it in the tourism business;

2. To determine how manifests the complementarity of the business models of the Klaipeda city incoming tourism companies (attributes, features of recognition);

3. To identify what factors determine the complementarity of the business models of the Klaipeda city incoming tourism companies.

Research methods: systematic analysis of scientific literature, comparative analysis. Research is based on the methodological approach of the qualitative research (case study). Data of the research were obtained by using the instrument of partially structured expert interview.

The article consists of three parts: theoretical scientific analysis, description of research methodology and presentation of research results and discussion.

The theoretically substantiated business model concept, concept of complementarity, scope of business model complementarity, theoretical characteristics, identification characteristics and factors in the incoming tourism are presented in theoretical scientific analysis section of article. The main result of this section of the article - the conceptual model of the complementarity of company business models and the factors that determine it in the incoming tourism, was constructed.

The second section of the article substantiates the methodology of the empirical research, based on the conceptual model of the complementarity of company business models and the factors that determine it in the incoming tourism that was prepared in the first section, by emphasizing the approach of the strategy of the qualitative research.

The third section of the article presents the results of empirical research, by revealing the characteristics of complementarity (nature, intensity, and orientation), 
characteristics of identification and determining factors in the incoming tourism. The obtained results of the qualitative research allowed to supplement and partially check the theoretical presumptions that were set in the previously section, formulate the conclusions of the research, and provide the further research directions.

\section{Restrictions of research:}

- companies and persons, who belong to the sector of the Klaipeda city (Lithuania) incoming tourism, were chosen for the research, by making the assumption that participation in this business causes the deeper understanding of complementarity. On the one hand it allowed to identify the complementarity between the selected organisation business models, but on the other hand, it prevented the answer to the question, whether the certain business sector and an institutional aspect affect the research results;

- research limited to the assessment of the complementarity of company level business models or their elements and the factors that determine it; complementarity was not assessed at the product, activity unit and industrial levels.

- only vertical complementarity at the micro level was analysed in the research, distancing from the manifestation of the activity unit complementarity that exist inside the company;

- it was maintained in the research that companies that formed functioning partnerships, have certain (basic) complementarity of business models. The presumption that the reasons of success of company partnerships are related not only to the compatible business models, but to another circumstances as well;

- qualitative research was performed by using a solitary case study. The collection of qualitative research data and analysis were performed by one researcher, and that caused certain one-sidedness of data contents and interpretation. The obtained empirical research data was applied only to the researched case of incoming tourism of the Klaipeda city (Lithuania).

\section{Literature review}

\subsection{Concept of business model}

The concept of business model (BM) has become a global object that is constantly analysed by the scientists and practitioners, it helps to strengthen the creation of value and directly affects the competitiveness of companies. In the recent years the definition of business model (BM) in the global works of the management science, is usually explained as: cooperation of suppliers, clients and partners; certain business logic; creation of an offer of a new value; measure for the development of the entrepreneurship, when creating the innovations, etc. (Wirtz et al., 2015). Therefore, author of this article defines business model as: a measure that helps to create a new value by uniting important elements inside and outside the company; a tool to identify and analyse the strategic choices of the company; and as a "frame" or a platform to analyse company relations, activities and their capabilities. Business model concept and its peculiarities are revealed in detail during the analysis of the business model structure and the elements that comprise it. Business model can be considered dynamic, as well as a static thing, but in this research it is defined more like static object: logical structure of actions and elements that help to create a new value; tool to identify the strategic choices of the organization and relations of companies, and to analyse the activities and capabilities. Explanation of the business model concept is supplemented by its structural components - elements. The point of view that is maintained in the research holds that the business 
model structure is composed of elements. Business model structure shows and explains mutual dependency and interaction of its components, when creating new value proposition. Business model structure has a rich variety of elements, therefore it is hardly understood how such multitude can be joined into a single system. Maybe this is the reason why scientists, who are offering structural elements of business model, failed to provide a single, established system for the formation of the structural elements of the business model (Kinderis \& Danielienè, 2019).

For the research was chosen Osterwalder and Pigneur (2009) business model instrument - the canvas stands out from alternative instruments lean canvas, fluid minds business model canvas, IBM's component business modelling, value model, four-box business model), because it allows not only to reduce the abstractness of business model concept, but also helps to reveal activity logic, specifics (and strategic choices) of researched companies, as well as to determine the interaction of structural elements in different business models during the empirical research. It also allows structurally and systematically displays the data that was received during the research.

\subsection{Concept of complementarity in the theory of inter-organisational connections}

Complementarity is the result of the interaction of homogeneous or heterogeneous units or their elements, when relations of independent units or their evolution creates higher value than their individual operation. Bidirectional orientation (symmetrical interaction) is characteristic to complementarity, but the intensity of orientation depends on the importance to the certain side. Complementarity can manifest due to the interaction of similar or different elements: strategic choices (essential choices in the activity of companies, in order to complete strategic objectives), business elements and means (business model structure elements: resources, partners, activities, consumers, value proposition, distribution channels, relations with consumers, cost and income). The larger number of the aforementioned elements interacts more intensively between different companies, the higher the probability for the occurrence of complementarity. Complementarity also reflects certain concord of similarities and differences between the interacting units (Porter \& Siggelkow, 2008; Cavaco \& Crifo, 2014). The complementarity of two typed nature is discerned, depending on the similarities or differences of the mutually interacting elements: "symbiotic" (occurs, when added value is created by interaction of different elements) and "accumulative" (occurs, when added value is created by interaction of similar elements) (Grandori \& Furnari, 2009; Ennen \& Richter, 2010). In the research it is intended to research the complementarity at the microlevel that reflects the result of the interaction between two or more companies, according to the logic of systematicity in the incoming tourism. Complementarity at the micro level manifests, when two or more companies unite their activities, resources and other business elements for a general new and better potential result that would not be achieved by acting separately or due to the elimination of present deficiencies. Author of the article discerns certain complementarity identification characteristics: clear changes in the specific activity of companies or business model (increased value proposition; increased number of consumers), higher concord of cooperating company activity and their business model (activity configuration, improved reach of consumers, improved relations with consumers, more effective use of resources, improved economy of activity), quicker application of innovations in the activity (faster decision making speed and higher competence) (Streeck \& Thelen, 2005; Baden-Fuller \& Morgan, 2010).

The following traits of complementarity identification in business formations: a 
higher degree of obligations; more active monitoring of partner's behaviour and its control formally, as well as informally; increased decision making speed; increased mutual trust; more intensive provision of tourism services and growth of productivity; appearance of a new consumer segment; increase of sale channel number; increase of a company entrepreneurship level; increased resource consumption potential; appearance and development of new and innovative activities, communication forms; cost saving, increasing of income flows (Filatotchev et. al., 2008, Kuvasana et. al., 2016).

\subsection{Business model complementarity and the factors that determine it in the incoming tourism}

Complementarity of business models is the result of the interaction between structural elements of company business models, when their business models or their individual elements strengthen/emphasise advantages of each other or reduce/eliminate disadvantages and together create higher value than when functioning individually. Certain traits and identification characteristics are attributed to the business model complementarity. Complementary business models create complex adaptive business system due to the interaction of their similarities and differences. Business model complementarity forms distinctive configuration of social and economic value generating throughout the whole business system (Ennen\& Richter, 2010; Cavaco \&Crifo, 2014; Androniceanu et al., 2019).

Business model complementarity is affected by the changes of the external environment (technological, political-legal, socio-cultural, economic and naturalecological - external factors), as well as changes of the internal environment of the organisation (organizational, management; economic-financial; human, cultural, physical-technological-internal factors) (Kracht \& Wang, 2010).

Cases of business formation successful existence, as well as cases of failure reveal the factors that determine the (none) complementarity of business models. The premise that the reasons for unsuccessful partnerships of companies (business formations) can be related not only to the difference of business models, but also to their similarity, cannot be disregarded as well (Chesbrough, 2007; Nenonen \& Storbacka, 2010).

The author of the article, based on the systematic approach and the analysis of scientific literature, presents a conceptual model of complementarity of business models and its determinants in incoming tourism (figure 1).

In the first (central) part of the model nine elements of company business models are discerned, in the research they are equated to the analysis units of the company business model complementarity (BMC). Since the complementarity of company business models is researched at the same time, but only between two companies, therefore two companies "A" and "B" are displayed in the model. The result of an interaction between two structural elements (BMC analysis units) of company business models is deemed to be complementarity that is characterised by the certain intensity and orientation, and acquires certain nature (complementarity due to similarities or differences: "symbiotic", "accumulative") in the context of the earlier discerned strategic choices. Also the BMC identification characteristics are presented in the conceptual model, these characteristics allow to ascertain complementarity between business models of researched companies: increased value proposition, increased number of consumers, improved reach of consumers, improved relations with consumers, activity configuration and concord, quicker decision making speed and higher competence, more effective use of resources, increased economy of activity. Part of this model is prepared according to 
the obtained findings, by analysing the concepts of the business model complementarity, theory of inter-organisational connections and potential premises of complementarity in the incoming tourism that are discussed in it (Dyer \& Singh, 2007; Osterwalder \& Pigneur, 2009; Casadesus-Mansell \& Ricart, 2010; Schallmo \& Brecht, 2010; Ennen \& Richter, 2010; Wirtz et al., 2015). In the presented model nine groups of strategic choices are discerned - one or two choices in each element/interaction unit of business model structure.

Figure 1 Conceptual model of business model complementarity (BMC) and of the factors that determine it in the incoming tourism

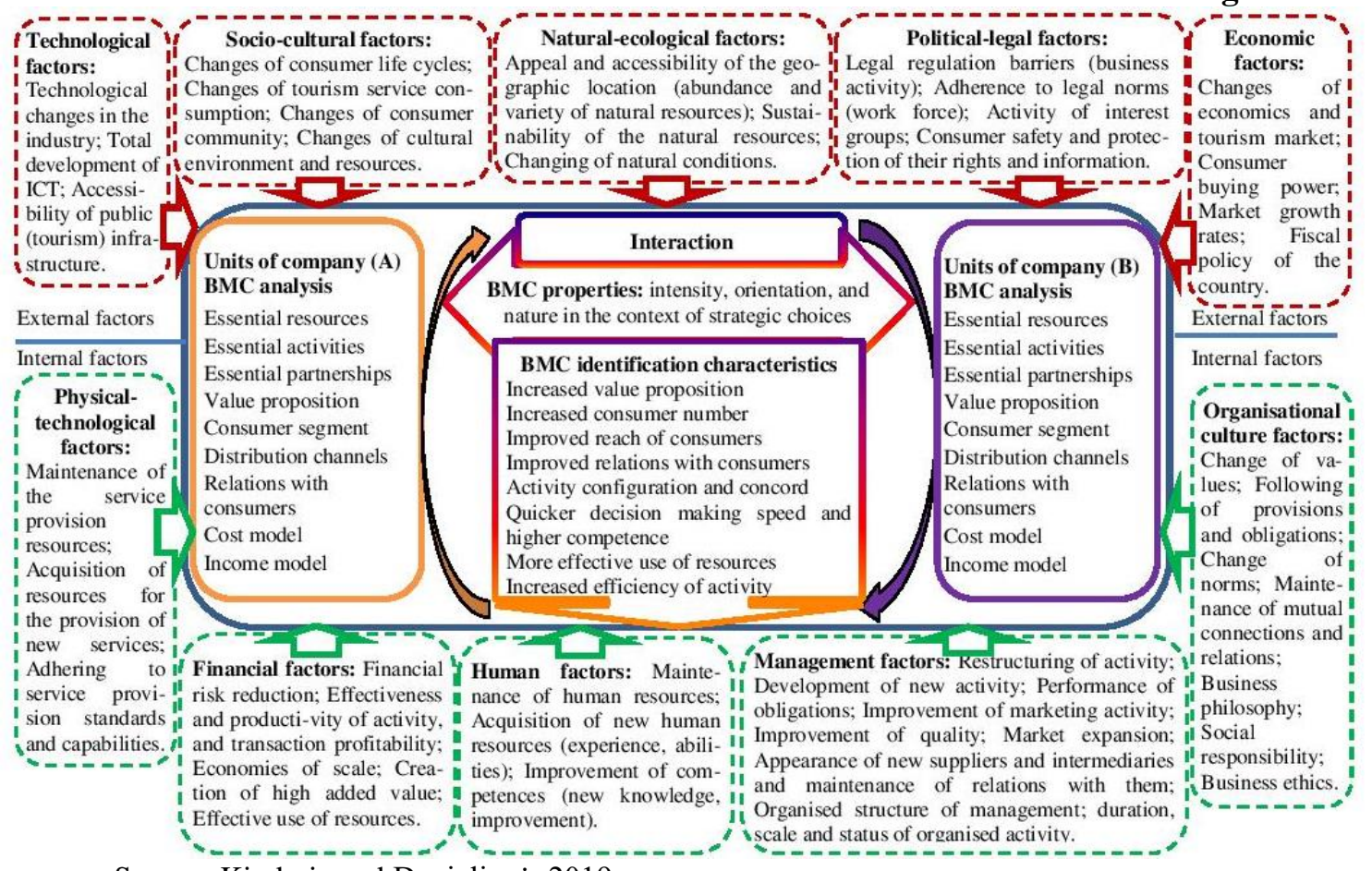

Source: Kinderis and Danielienè, 2019

In the second part of the presented model two factor groups of are discerned, they determine the complementarity of the business models of the incoming tourism companies: internal and external factors. This section of the model is prepared by taking into consideration the obtained findings, and analysing the theory of business models and inter-organisational relations (tourism alliances, tourism clusters), and the structure of the incoming tourism. Author of the article decided to present namely the following classification of factors that were discerned in the theoretical discussion, taking into consideration recommendations provided in the works of scientists: Buhalis \& Law (2008), Kracht \& Wang (2010), Johnson et al. (2011), and Eungblut (2013). The group of external factors is comprised of: technological, socio-cultural, natural-ecological, political-legal and economic factors and the group of internal factors is comprised of: economic-financial, human, physical-technological, management, organizational culture, and the size and status of the company. The aforementioned factors affect business models, their activity and interaction in the incoming tourism in one way or another. Discerned factors can disrupt, alter or promote occurrence of complementarity in the incoming tourism.

\section{Research methodology}


To carry out research on complementarity and its determinants, researchers suggest combining quantitative and qualitative research and the methods used in them. Qualitative research methods are well suited for processes that take place between collaborating business participants and for analysing their results. Scientists Zott and Amit (2010), Teece (2010), Chesbrough (2010), recommend using a qualitative research case study method with in-depth or partially structured interview to investigate certain inter-organizational relationships and interactions between them. The data obtained and analysed in the case study is easily compared with the expected theoretical results (theoretical model). In order to investigate the complementarity of business models and their determinants in incoming tourism, qualitative research methods make it possible to better understand how elements of business models interact, the nature, intensity, purposefulness of the result of the interaction, features of recognition and factors that determine it. Applying qualitative research and its methods helps to understand and identify certain things, though not to evaluate them, allows the researcher to explore real business experience by treating the subjects as independent objects, ignoring their ability to consider the situation of the problem and act according to the acquired experience, but it is difficult to ask the subjects to reflect what they do subconsciously (Cavaye, 1996; Coviello et al. 2011; Kinderis, 2019).

The intention of qualitative research was not to verify already formulated theoretical statements about the complementarity of business models and the factors that determine it, i. e. verify their correctness, but to perform the scientific surveillance, i. e. to describe and analyse the selected learning object, i.e. to get more data about the subject that was researched little, and to create hypothetical object model for further inspection on the basis of this data. According to the systemic approach, it was tried to reveal the research object and the traits, characteristics and factors that define it, and to delve into them. Since the methodological approach of the qualitative research openly emphasize object's dependency on the environment and on the context, therefore this research was intended to reveal the peculiarities of the object in the natural environment (in the business environment of the Klaipeda city incoming tourism), and to connect the obtained results with certain real and specific conditions and contexts of the incoming tourism business.

An integrated incoming tourism business case in the Klaipeda (Lithuania) was chosen because it is the most representative case of the incoming tourism system in Lithuania and includes all its mandatory elements. The companies that participated in the study belong to the region of destination of tourists, as they operate directly in the region where the tourists arrive (Klaipeda city, Lithuania). Klaipeda is a Lithuanian seaside city that attracts tourists traveling by cruise ship, plane and land transport.

While researching the business model complementarity of companies and the factors that determine it in the incoming tourism, it can be stated that the most suitable is the approach of the qualitative research, by employing partially structured interview (Teece, 2010; Chesbrough, 2010). From the point of view of the author, in order to achieve the objective, the most expedient was to follow the strategy of the phenomenological case study, in which the complementarity of business models is considered a phenomenon. The case of the research is the business model complementarity of travel organizer and its partners. Due to the complex nature of the tourism product there are no possibilities to identify and research the complementarity of business models of all members that comprise the structure of the Klaipeda city incoming tourism and the factors that determine it, therefore it was confined to the interaction analysis of business models and elements thereof of one travel organizer and its main 
business partners (hotel, restaurant, carrier and guide), that create and provide the product of incoming tourism in the Klaipeda city the entire year. Therefore, the analysis units for the study of this case are travel organizer and its partners (hotel, restaurant, carrier, guide), and research subjects - their managers. In the research it was distanced from the internal and procedural expression of complementarity in the company business model itself - between its elements. Travel organizer's and its partners business model complementarity is considered to be an intrinsic interpretative single case study with several units of analysis in one and the same context, it is purposefully selected from the general set of business models of incoming tourism business units. Internal research study of one case with several analysis units was selected due to several reasons: 1) business model complementarity is a phenomenon that is researched very little, therefore such case can be deemed critical and unique; 2) the case is researched for its deeper understanding, it is also tried to resolve specific problems at the sufficiently individual level of the case, and not generalise the obtained results; 3 ) the results of a case study are intended for use to complement the theory of inter-organisational relations and business models, and not for its testing; 4) it is intended to research situations in which the application results of evaluation interventions are not clear; 5) the integration of few units of analysis into a study of one case and cross- case unit analysis serves for a deeper understanding of the case (Yin, 2003; Lueg et al., 2016).

It can be noted that the evaluation criteria system for the incoming tourism company business model complementarity and the factors that determine it, was prepared with respect to the level criteria of companies, with which the research and assessment of company business model complementarity begin (Kinderis, 2019).

The complementarity of the incoming tourism business models are researched according to the discerned analysis units of the business model complementarity and the criteria of three groups that define it (characteristics: intensity, orientation, nature), and the factors that determine it (two groups of factors) and the characteristics of identification are identified. Nature of business model complementarity can be: "symbiotic" (because of the dissimilarity), "accumulative (because of the similarity)"; intensity (between business model (BM); between BM structural elements; between strategic choices in BM: very weak, weak, average, strong, very strong; orientation: between BM (dominating mono-directional/bidirectional) (Hammersley, 2011; Bryman, 2016).

Target sample creation method was chosen to be applied in the research-mixed target selection, combining several research sample identification methods: selection of critical cases and criterial selection. The experts for the research were selected with respect to two criteria: documentary, when the competence of the expert is evaluated according to the social information and self-evaluation of the expert. With respect to the objective of the empirical research, the expert was the manager of the highest level, with no less than 5 year managerial work experience in the analysed company of an incoming tourism and the experience in cooperation with a partner. Potential experts had to specify own interest in the problem that is being examined and assess own capabilities to provide valuable information to the research. All experts ( 5 persons), who participated in the research, were interested in the examined problem and felt like they can provide data necessary for the information. During the selection of companies the criterial selection was applied. Sample units from population (general set) were selected, and by following the criteria set by the researcher: company that is engaged in incoming tourism in the Klaipeda city and is operating for no less than 5 years; company that maintains partnership with the travel organiser that participates in the research, for no less than 5 years, together creating the product of incoming tourism for the entire year in the Klaipeda city. 
During the performance of the research the research participants were questioned, by using individual questionnaire of partially structured interview, created according to the conceptual model of the business model complementarity and the factors that determine it in the incoming tourism (Kinderis, 2019).

The research instrument consisted of 9 blocks of questions to help determine complementarity and the factors that determine it, thanks to the help of business model complementarity analysis units: value proposition, consumer segment, delivery channels and availability, consumer relations, essential partnerships, key resources and abilities, core activities, costs structure, income streams. The importance and meaning of each business model complementarity analysis unit was asked on a five-point scale, where 1 point meant that it was not relevant to the complementarity of business models, and 5 points meant it was very important. The concept of importance in the context of this research is equated with intensity. The instrument was developed taking into account the business model structure and its logical sequence as outlined by Osterwalder and Pigneur (2009) and the most important theoretical findings on the complementarity and business determinants of business models presented in the theoretical part. The interviewees were contacted directly and verbally, which allowed them to comment more on their answers and to justify them. Interview data were collected and recorded in cross-way: tour operator + hotel, hotel + tour operator; travel organizer + restaurant, restaurant + tour operator, etc. In this way, a minimum of 10 points could be scored and a maximum of 90 points was awarded to assess the complementarity of the business models of the two companies. Therefore, taking into account the sum of the collected points, the intensity of the complementarity of the business models of the companies was evaluated: very weak (10-18 points), weak (19-36 points), average (37-54 points), strong (55-72 points), strong (73-90 points). In this research business model complementarity (characteristics: nature, intensity, orientation; identification characteristics) of companies and the factors in the Klaipeda city incoming tourism that determine it, were identified (Kinderis \& Danielienè 2019).

In order to ensure and substantiate the internal validity of the research, the report was presented to the research subjects, in order to find out what they think about the correctness of the research report. It was also ascertained, whether the obtained results of the research are accurate and easily understandable. It was also tried to ensure the internal validity by: the direct participation of the researcher himself in the research; using mechanical data recording and storage means; the control of the participants (took place after the collection of data and by analysing them: calling in order to check the accuracy of the collected facts).

The external validity in the qualitative research is used in order to reveal the peculiarities of the research result application in the general set. Therefore, the intention of the research was the presentation of conclusions that would allow to understand where the obtained research results could be applied.

Reliability of the performed research is based on the instruments substantiated by the research technique, prepared in advance, and on the properly collected and analysed research data. With respect to the research object understanding that is getting deeper, the researcher, respectively changed the design of the research and flexibly adapted the methods of the research. Questionnaire was prepared in accordance with the recommendations presented by Bryman (2016): questions were clear and understandable to the research subject; had an exploratory nature; were related to the statements purified in theory and maintained logical connection with one another; questions were not too wide and were not too narrow. Also by taking into consideration the recommendations offered by Kvale (1996) for the presentation of different type questions, the questions 
were of: introductory, leading, attention, specialised, direct, indirect, structuring and interpretive nature. The researcher was able to properly prove and argument the necessity of the changes of research design and employed methods, because the research procedure performance or method application logic cannot be changed "anyway" and "any time".

Research discerns one group of ethics principle - ethics with respect to the research subjects. Therefore, the majority of the attention was given for the assurance of the research subject treatment ethics. First of all the research was performed according to the principle of free will, equality and in formativeness. Anonymity of research subjects and confidentiality of the obtained information was ensured by not disclosing their identity, and the obtained (non-processed) information will not be accessible to anybody else, except for the participants of the research.

Data obtained were analysed and compared from two approaches (Bitinas et al., 2008): Quasistatic and Model. The research data was analysed and presented by structuring it into tables and describing in the text, i. e. by using structural and interpretive data analysis types in the research.

According to Saunders et al. (2009), during the research, the procedure of the following steps was used in the analysis of the data of each interview: 1) Preparation of transcripts and "feeling out" each of them; 2) Formulation of sub-topics and topics, by discerning and merging semantic units; 3) Thorough and consistent description of the case analysis according to the structure; 4) Return to informants.

For the presentation of the research data the linear method that is also known as Linear-Analytical was chosen. This method is suitable for the performance of the presentation of the results of the case studies that are being researched, it is considered standard, with the logic sequence that includes: analysis of a scientific literature, selection of methods, collection of data, its analysis, and presentation of conclusions and insights of further research guidelines. It is one of the most suitable methods for data presentation in the academic and scientific works (Runeson et al., 2012).

\section{Results of the research}

The identification of business model complementarity traits and identification characteristics, as well as factors that determine it in the Klaipeda city incoming tourism was made in the research. Eight interviews were performed (four cross interviews) and the research data analysis is presented according to the business model complementarity analysis units that, with respect to the recommendations of the qualitative research methodology, are purified by performing the data abstraction and equated to topics and sub-topics. The summary of research data analysis presented in a structured way: Business model complementarity of travel organizer (TO) and its business partners: nature, intensity, orientation; characteristics of identification and factors that determine business model complementarity in the incoming tourism of the Klaipeda city.

Therefore, by summarising business model complementarity of the travel organizer (TO) and all of its partners (accommodation companies - AC, catering companies - CC, carrier's companies - CrC and information provider's guide - IPG) according to the criterion - intensity between structure elements of BM (analysis units), it can be stated that the complementarity in the business models of the researched companies most strongly manifested in the analysis units of the essential partnerships, value proposition, distribution/accessibility, consumer segment and resources, and the abilities. The weakest complementarity presented in the analysis units of cost structure, income flows, essential activities and relations with consumers (figure 2). 
By summarising the complementarity of business models of travel organiser (TO) and all of its partners ( $A C, C C, C r C, I P G)$ according to the criterion - intensity between business models, it can be stated that complementarity manifested the most strongly between business models of TO-IPG-TO (69 points), and the weakest complementarity was recorded between the business models of TO-AC-TO (41 point) (figure 2).

Figure 2 Intensity of the business model complementarity of TO and its partners (AC, $\mathrm{CC}, \mathrm{CrC}, \mathrm{IPG})$ and its orientation in the units of analysis

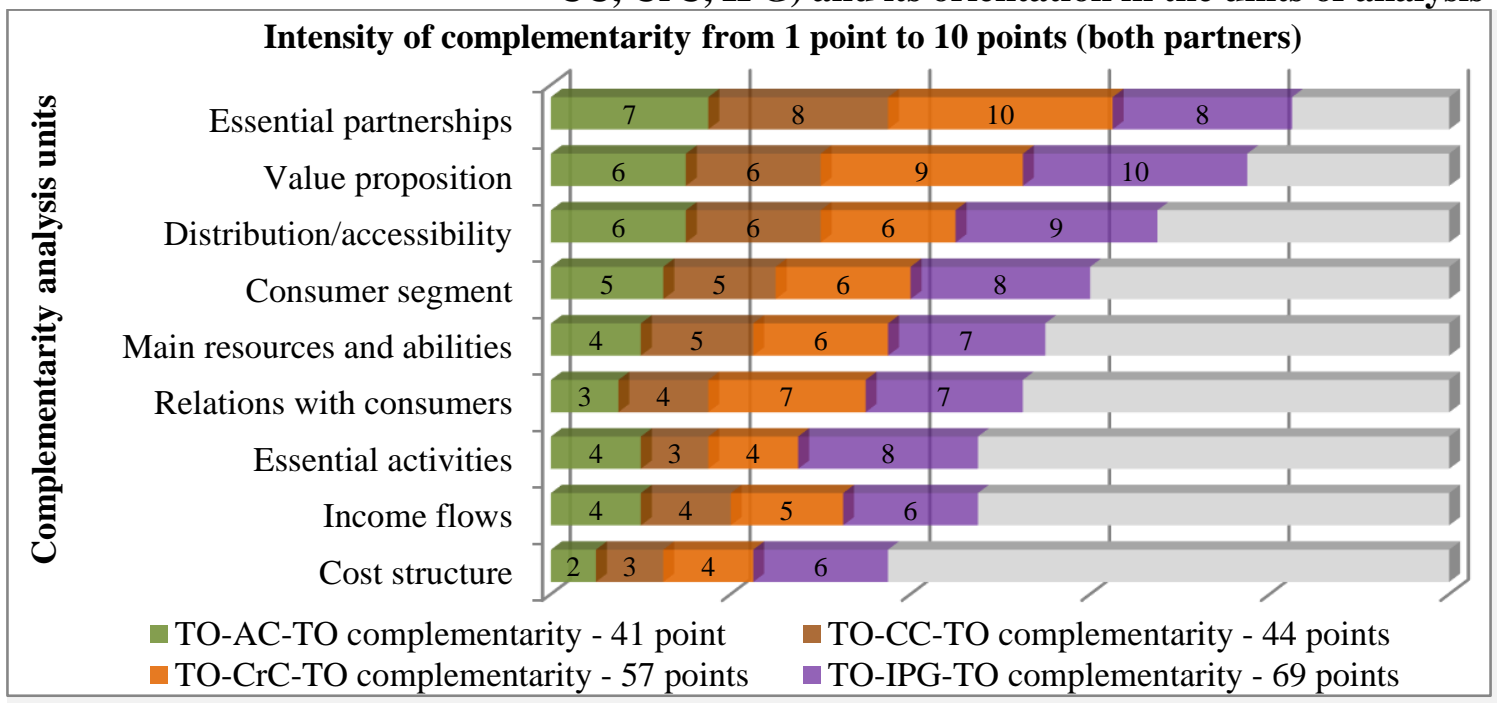

Source: authors' own work

The intensity of the business model complementarity of the researched companies can be attributed to that of an average strength (TO-AC-TO and TO-CC-TO) and to the strong one (TO-CrC-TO and TO-IPG-TO). It is explained by the fact that TO is the most interested in the performance of its main activity - create and realise the product of the incoming tourism and receive income from it. In order for such a product to be created, the services of transportation, accommodation, catering, information provision and other tourism services must be provided, usually travel organiser is unable to provide them by himself - a partnership is necessary.

By evaluating the business model complementarity of the researched companies according to the criterion - intensity between strategic choices in the business models, it can be stated that complementarity is stronger, when: essential partnerships are maintained, when seeking identical goals; at least one of the activities is shared; distribution channels and the value proposition creation strategy match; the work is done and the relations are maintained with at least one and the same consumer segment and the missing resource is reached by having similar philosophy of its use.

When evaluating the business model complementarity of researched companies according to the criterion - orientation between business models, it should be noted that the orientation of business model complementarity of TO and its partners is exclusively mono-directional: TO is more interested in the mutual cooperation that its partners (figure 3).

During the evaluation of the complementarity of business models of the researched companies according to the criteria-nature, it can be stated that the nature of the complementarity of business models of all researched companies is "accumulative", due to the similarities of the dominating elements and the compatibility of strategic choices in the business models (figure. 3). 
Figure 3 Intensity and orientation of TO and its partner business model complementarity

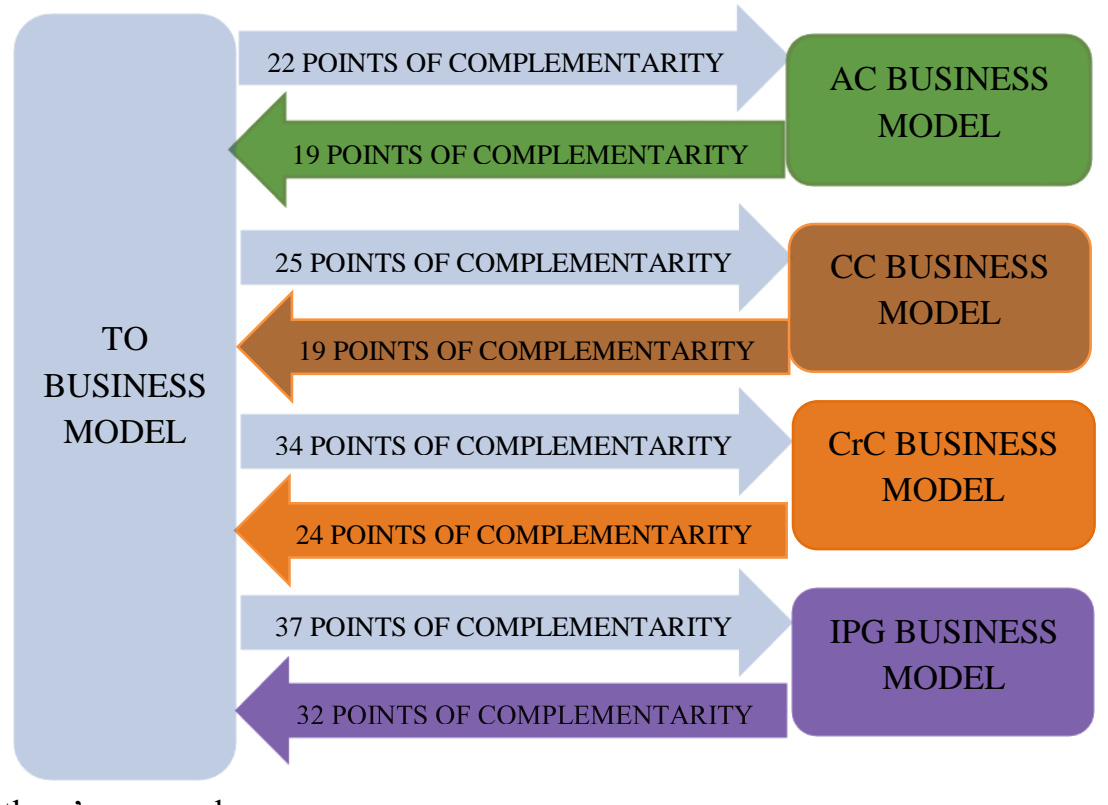

Source: authors' own work

During the evaluation of the identification characteristics of business model complementarity, it can be stated that the most intensively manifested: increased number of consumers, increased decision making speed and higher competence, as well as increased economy of activity. It is also possible to make a presumption that traits of complementarity directly correlates with the characteristics of identification.

Hereinafter are presented factors that determined company business model complementarity - its intensity, orientation and nature that were identified during the research. The groups of internal factors influenced the complementarity of the analysed company business models more than groups of the external factors. All groups of the internal factors that were discerned in the theoretical model have manifested, but not all of the factors that were in those groups (Kinderis and Danieliene, 2019). Factors that did not manifest: financial risk reduction, financial efficiency of the activity, economies of scale, human resource acquisition and maintenance, development of a new activity, structure of organisation management, duration of organisation activity, adherence to the behavioural norms, size and status of the organisation. From the external factors the expression of business model complementarity was mostly affected by the groups of the economic, technological and socio-cultural factors. Only two of the external factor groups completely unaffected the complementarity expression of the analysed business models: natural-ecological factors and political-legal factors. Non manifested factors: technological changes in the industry, general development of ICT, changes of consumer community, changes of cultural environment and resources, market growth rates, and fiscal policy of the country.

The author maintains the belief that only the presentation of the approach to the linear research results is not enough, therefore, after the results of the research are summarised, he presents them by schematically visualising in the model and recognizes that even systemic structuring and identification of this phenomenon provides the possibility to find only relative manifestation limits of the phenomenon that is being researched (figure 4). 
Figure 4 The model of the business model complementarity and the factors that determine it, in the incoming tourism

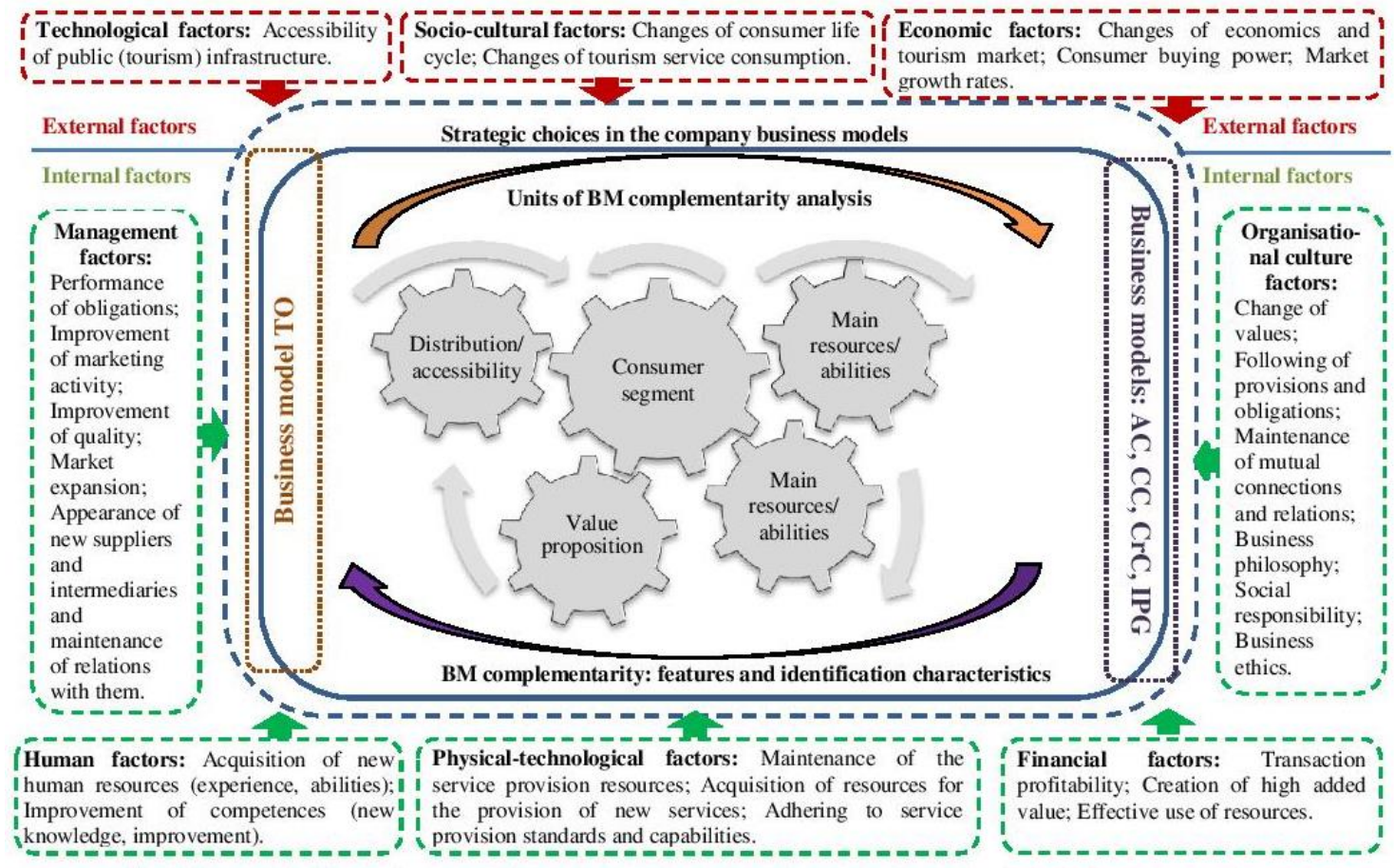

Source: authors' own work

It is likely that the model of company business model complementarity and the factors that determine it, created on the basis of the theoretical research and later verified empirically, allows to record complementarity between business models of two companies at the same time, and also to assess general complementarity of business models of all companies that were researched, in the chain of value creation and to identify the factors that determine it in the incoming tourism. The presented criteria for the identification of company business model complementarity can be applied during the research of complementarity in other business sectors as well.

\section{Discussion and Conclusion}

The research of traits and identification properties of the business model complementarity of the Klaipeda city incoming tourism companies revealed that:

- intensity of business model complementarity can be classified as average;

- intensity of business model complementarity most strongly manifested between the following units of analysis: essential partnerships, value proposition, distribution/accessibility, consumer segment and the analysis of resources and abilities, and manifested the weakest between analysis units of: cost structure, income flows, essential activities and relations with consumers;

- orientation of business model complementarity is exclusively mono-directional (travel organiser is more interested into mutual cooperation than its partners);

- the nature of business model complementarity is "accumulative" due to the similarities of the dominating elements and the strategic choice compatibility in the business model; 
- the following business model complementarity identification characteristics presented themselves: increased number of consumers, quicker decision making speed and higher competence, as well as increased economy of activity. The presumption can be made that traits of business model complementarity directly correlate with the characteristics of identification.

The research of the factors that determine the complementarity of the Klaipeda city incoming tourism company business models revealed that the groups of internal factors determine the complementarity of business models more strongly than groups of external factors. Scientists have proven that the success of an enterprise is determined by its internal factors as well as the complementarity of its business model. The following groups of internal factors are active and determine business model complementarity: financial factors (transaction profitability), creation of high added value, effective use of resources; human factors (acquisition of new human resources (experience, abilities)), improvement of competences (new knowledge, improvement); management factors (performance of obligations, improvement of marketing activity, improvement of quality, market expansion, appearance of new suppliers and intermediaries and maintenance of relations with them); physical-technological factors (maintenance of the service provision resources, acquisition of resources for the provision of new services, adhering to service provision standards and capabilities); organisational culture factors (change of values, following of provisions and obligations, change of norms, maintenance of mutual connections and relations, business philosophy, social responsibility, business ethics). Factors that did not manifest in the aforementioned groups: financial risk reduction, financial efficiency of the activity, economies of scale, human resource acquisition and maintenance, development of a new activity, structure of organisation management, duration of organisation activity, adherence to the behavioural norms, size and status of the organisation. The following groups of external factors are active and determine business model complementarity: technological factors (accessibility of public tourism infrastructure), socio-cultural factors (changes of consumer life cycle, changes of tourism service consumption), economic factors (changes of economics and tourism market, consumer- buying power, market growth rates). The following factors of the aforementioned groups did not manifest: technological changes in the industry, general development of ICT, changes of consumer community, changes of cultural environment and resources, market growth rates, and fiscal policy of the country.

The most important meaning of this research is that the complementarity of the incoming tourism company business models was researched through the prism of business models, by employing certain qualitative evaluation criteria of strategic management, inter-organisational relations and complementarity. Business model complementarity and the research context of the factors that determine it, included: analysis units of cooperation principles, resource and activity compatibility, creation of value proposition, consumer segment and maintenance of relations with them, distribution channels, as well as cost and income compatibility, and the moments of strategic choices. This thesis stands out from other theses with its prepared original research methodology for business model complementarity, identification characteristics and the factors that determine it, testing of that methodology and consistent presentation of results.

Research has a clear perspective of future research and provides theoretical methodological basis for further research of complementarity: it is appropriate to check the conceptual model of complementarity and the factors that determine it, prepared on the basis of theoretical and empirical research, as well as to evaluate through the additional research in the different business sectors and different levels of business model 
dependency: activity, product or even industry. In the future, it is relevant to perform wide and comprehensive research of business model complementarity phenomenon, by applying in-depth interview, focus group and other research methods that would provide a possibility to reveal more comprehensive expressions of the phenomenon that is analysed, to adjust and supplement its parameters, and to identify the connections of causation, improving the available methodology of the research. The possibility to research in the future the internal complementarity in the single organisation or by better integrating procedural and network approaches is also not rejected.

Research results can be used in several practical fields of activities as well: the conceptual model that was formed allows for activity practitioners to understand systematicity of company business model complementarity even better, its essential traits, identification characteristics and factor the concord and importance; the obtained results of the research provides deeper insights and allows to strengthen managerial impact to the creation and development of the potential partnerships; the research methodology for the business model complementarity and the factors that determine it in the incoming tourism is easily adaptable for the determination of business model complementarity of companies that operate in other business systems; modified research instrument (based on proven theoretical model) is sufficiently universal and can be considered as a diagnostic tool for inter-organisational relations, it can be used to determine and evaluate the complementarity of company business models in various business systems.

\section{References}

1. Androniceanu, A., Gherghina, R., Ciobanasu, M. (2019). The interdependence between fiscal public policies and tax evasion, Administratie si Management Public, (32), pp. 32-41, DOI: 10.24818/amp/2019.32-03.

2. Androniceanu, A. (2017). The three-dimensional approach of Total Quality Management, an essential strategic option for business excellence, Amfiteatru Economic, 19(44), 61-78.

3. Baden-Fuller, C., \& Morgan, M.S. (2010). Business models as models. Long Range Planning, 43(2-3), 156-171.

4. Bitinas, B., Rupšienè, L. ir Žydžiūnaitè, V. (2008). Kokybinių tyrimy metodologija. Klaipėda: S. Jokužio leidykla-spaustuvè.

5. Bryman, A. (2016). Social Research Methods. London: Oxford University Press.

6. Buhalis, D., \& Law, R. (2008). Progress in informatikon technology and tourism management: 20 years on and 10 years after the Internet-The state of eTourism research. Tourism management, 29(4), 609-623.

7. Casadesus-Masanell, R., \& Ricart, J.E. (2010). From strategy to business models and onto tactics. Long Range Planning, 43(2-3): 195-215.

8. Cassiman, B., \& Veugelers, R. (2006). In search of complementarity in innovation strategy: internal RandD and external knowledge acquisition. Management Science, 52 (1), 68-82.

9. Cavaco, S., \& Crifo, P. (2014). CSR and Financial Performance: Complementarity between Environmental, Social and Business Behaviours. Applied Economics, 46 (27), 3323-3338.

10. Cavaye, A.L.M. (1996). Case study research: a multi-faceted research approach for IS. Information systems journal, 6(3), 227242.

11. Chesbrough, H. (2007). Business model innovation: it's not just about technology anymore. Strategy and Leadership, 35 (6), 12-17. 
12. Chesbrough, H. (2010). Business model innovation: opportunities and barriers. Long Range Planning, 43 (2/3), 354-363.

13. Coviello, N. E., McDougall, P.P, \& Oviatt, B.M. (2011). The emergence, advance and future of international entrepreneurship: An introduction to the special forum. Journal of Business Venturing, 26 (6), 625- 631.

14. Dyer, J., \& Singh, H. (1998). The relational view: Cooperative strategy and sources of interorganizational competitive advantage. Academy of Management Review, 23 (4), 660-679.

15. Ennen E., \& Richter A. (2010). The Whole is More Than the Sum of Its Parts Or is It? A Review of the Empirical Literature on Complementarities in Organizations. Journal of Management, 36 (1), 207-233.

16. Filatotchev, I., Stephan, J., \& Jindra, B. (2008). Ownership structure, strategic controls and export intensity of foreign invested firms in emerging economies. Journal of International Business Studies, 39 (7), 1133-1148.

17. Ganushchak-Efimenko, L., Shcherbak, V., \& NifatovaO. (2018). Assessing the effects of socially responsible strategic partnerships on building brand equity of integrated business structures in Ukraine. Oeconomia Copernicana, 9(4), 715730. https://doi.org/10.24136/oc.2018.035.

18. Grandori, A., \& Furnari S. (2009). Types of Complementarity, Combinative Organization Forms and Structural Heterogeneity: Beyond Discrete Structural Alternatives. In: M.Morroni (Ed.). Corporate Governance, Organization and the Firm: Co-operation and Outsourcing in a Globalised Market. London, UK: Edward Elgar. (pp. 63-86). Retrieved August 25, 2019, from http://openaccess.city.ac.uk/id/eprint/3065

19. Hammersley, M. (2011). Methodology: Who Needs It? London: Sage. DOI: 10.4135/9781446287941

20. Johnson, M.W., Christensen, C.M., \& Kagermann, H. (2008). Reinventing your business model. Harvard Business Review, 86 (12), 51-59. Retrieved August 27, 2019, from http://radio.shabanali.com/reinventing-your-business-model.pdf

21. Kaplan, S. (2012). The Business Model Innovation Factory: How to Stay Relevant When The World is Changing. John Wiley \& Sons, Inc., Hoboken, New Jersey.

22. Kavusana, K., Noorderhavenb, N.G., \& Duysters, G.M. (2016). Knowledge acquisition and complementary specialization in alliances: The impact of technological overlap and alliance experience. Research Policy, 45, 217-233.

23. Kinderis, R. (2019). The research methodology of the business model complementarity and the factors that determine it in the inbound tourism. Development and transformation processes in the tourism industry under the conditions of globalization. Klaipeda: Klaipeda State University of Applied Sciences. ISBN 978-609-454-384-5, 31-42.

24. Kinderis, R., \& Danielienè, J. (2019). Business model complementarity and the factors that determine it in tourism business formations: the theoretical aspect. Society. Integration. Education. Proceedings of the International Scientific Conference, (VI), 258-268. Retrieved August 15, 2019, from http://journals.ru.lv/index.php/SIE/article/view/3688/3907

25. Kracht, J., \& Wang, Y. (2010). Examining the tourism distribution channel: evolution and transformation. International Journal of Contemporary Hospitality Management, 22 (5), 736-757.

26. Kvale, S. (1996). InterViews: An Introduction to Qualitative Research Interviewing. Thousand Oaks, CA: Sage. 
27. Lee, C.S., Ze, Y., Chen, Y.G., \& Fan, Y.H. (2006). Structure and Components of E-Commerce Business Model, Encyclopedia of E-Commerce, E-Government, and Mobile Commerce. M. Khosrow-Pour (ed.), 1058-1063. DOI: 10.4018/9781591407997.ch170.

28. Lueg, K., Lueg, R., Andersen, K., \& Dancianu, V. (2016). Integrated reporting with CSR practices: a pragmatic constructivist case study in a Danish cultural setting. Corporate Communications: An International Journal, 21 (1), 20-35.

29. Miravete, E., \& Pernias, J. (2006). Innovation complementarity and scale of production. Journal of Industrial Economics, 54, 1-29.

30. Nenonen, S., \& Storbacka, K. (2010). Business Model Design: Conceptualizing Networked Value Co-Creation. International Journal of Quality and Service Sciences, 2(1), 43-59.

31. Olinski, M., Szamrowski P., \& Luty L. (2016). The Impact of EU Funds on the Development of a Business Model for Small and Medium-Sized Enterprises. Journal of Competitiveness, 8 (3), 68-89 https://doi.org/10.7441/joc.2016.03.05

32. Osterwalder, A., \& Pigneur, Y. (2009). Business model generation: A handbook for visionaries, game changers, and challengers. Self published. Retrieved August 18, 2019, from http://alvarestech.com/temp/PDP2011/pdf/Business\%20Model\%20Generation\% 20(1).pdf

33. Porter, M., \& Siggelkow, N. (2008). Contextuality within activity systems and sustainability of competitive advantage. Academy of Management Perspectives, 22, 34-56.

34. Rivkin, J.W. \& Siggelkow, N. (2003). Balancing search and stability: Interdependencies among elements of organizational design. Management Science, 49, 290-311.

35. Runeson, P., Host, M., Rainer A., \& Regnell, B. (2012). Case Study Research in Software Engineering - Guidelines and Examples. Wiley.

36. Saunders, M., Lewis, P., \& Thornhill, A. (2009). Research methods for business students, 5th ed. Harlow, Pearson Education.

37. Schallmo, D.R.A., \& Brecht, L. (2010). Business Model Innovation in Businessto-Business Markets - Procedure and Examples. The Proceedings of the 3rd ISPIM Innovation Symposium. Canada: Quebec.

38. Slávik, Š., \& Zagoršek, B. (2016). Relationship between Business Strategy and Business Model Studied in a Sample of Service Companies. Journal of Competitiveness, 8 (4), 72-84 https://doi.org/10.7441/joc.2016.04.05

39. Streeck, W., \& Thelen, K. (2005). Introduction. In Streeck, Wolfgang and Kathleen Thelen (eds.). Beyond Continuity: Institutional Change in Advanced Political Economies. Oxford: Oxford University Press.

40. Świadek, A. (2018). Sales range and innovative activity in the manufacturing system of Poland. Equilibrium. Quarterly Journal of Economics and Economic Policy, 13(4), 725-740. https://doi.org/10.24136/eq.2018.035.

41. Świadek, A., Dzikowski, P., Tomaszewski, M., \& Gorączkowska, J. (2019). Sectoral patterns of innovation cooperation in Polish industry. Equilibrium. Quarterly Journal of Economics and Economic Policy, 14(1), 183-200. https://doi.org/10.24136/eq.2019.009.

42. Teece, D.J. (2010). Business models, business strategy and innovation. Long Range Planning, 43 (2-3), 172-194. 
43. Verstraete, Th., \& Estèle, J. (2011). A Conventionalist Theory of the Business Model in the Context of Business Creation for Understanding the Organizational Impetus. Management International, 25(2), 109-124.

44. Wirtz, B. W., Schilke, O., \& Ullrich, S. (2010). Strategic development of business models implications of the Web 2.0 for creating value on the internet. Long Range Planning, 43, 272-290, 1-19.

45. Yin, R.K. (2003). Case study research: Design and methods (3rd ed.). Thousand Oaks, CA: Sage.

46. Zott, C., \& Amit, R. (2010). Business model design: an activity system perspective. Long Range Planning, 43 (2-3), 216-226.

\section{Brief description of Author:}

\section{Assoc. Prof. Dr. Remigijus Kinderis}

Business Administration Department, Business Faculty, Klaipeda State University of Applied Sciences, Jaunystes str. 1, Klaipeda, Lithuania, www.kvk.lt, r.kinderis@kvk.lt. Faculty of Management and Social Sciences, Liepaja University, Lielā str. 14, Liepaja, Latvia, www.liepu.lv

Remigijus Kinderis works as an associate professor in Lithuanian and Latvian higher education institutions. The main field of research is tourism management, business models, tourism service quality. He is also expert of quality in the higher education system, the author and co-author of monograph and scientific articles. 